\title{
Evaluation of Efficacy diet supplemented with some local formulas on body weight and haematological parameters of rats
}

\author{
Naeem M. Rabeh', Hany G. El-Masry', Eman M. Ghallab', \\ Hanan M. Elghandour ${ }^{2}$, Abeer M. Hassanien ${ }^{1}$ \\ Nutrition and Food Science Department, Faculty of Home \\ Economics, Helwan University \\ Regional Center for Food and Feed, Agricultural Research Center.
}

\begin{abstract}
Some local traditional formulas have been commonly used based on the information of their popularity in local markets for gaining weight. Hence, the aim of this study was conducted to evaluate the effect of some local prepared formulas (Mefataka, Kharaz El-Bakar, Tahwijat El-kortas El-Abiad) on body weight, hematological parameters and their efficacy in case of long-term consumption ( 8 weeks), using experimental animals. Forty two adult male albino rats were divided into seven groups (6 rats each), group (1) was fed on basal diet and kept as a control group, groups (2 and 3) were fed on basal diet supplemented with formula (1) "Mefataka", at the level of $10 \%$ and $15 \%$ of the rats diet respectively. Groups (4 and 5) were fed on basal diet supplemented with formula (2) "kharaz El-Bakar", at the level of $10 \%$ and $15 \%$ of the rats diet respectively. Groups (6 and 7) were fed on basal diet supplemented with formula (3) "Tahwijat El-kortas El-Abiad" at the level of $10 \%$ and $15 \%$ respectively. The chemical composition of studied formulae Mefataka, Kharaz El-Bakar and Tahwijat El-kortas El-Abiad provided caloric value of 337.01, 346.44 and $395.7 \mathrm{~K} . \mathrm{cal} / 100 \mathrm{~g}$ dried sample respectively. The results indicated that the body weight gain percent and feed efficiency ratio were increased significantly $(P<0.05)$ in rats fed on their formulae, compared to the control group. Also, significant increase $(P<0.05)$ in the levels of hematological parameters and leptin hormone were observed, however, there were no significant changes in liver and kidney functions, compared to the control group. Conclusion: The tested formulae increased the weight of rats without any harm on body systems. A trial of using these formulae on slim human seeking an increase in body weight is recommended.

Key words: Weight gain formulas, liver and kidney functions, hematological profile, chemical composition, leptin hormone, body weight.

\section{Introduction}

Underweight is typically defined as a body mass index (BMI) $<18.5 \mathrm{~kg} / \mathrm{m}^{2}$ (World Health Organization, 1998). Underweight may also be defined as $15 \%$ to $20 \%$ lower than the standard weight for a person's age and height (Mahan and Escott-Stump, 2000). Malnutrition or underweight is increasingly recognized as a significant contributor to the global burden of diseases (Ezzati et al., 2002 and Gunaid and Assabri., 2008). The majority of underweight women of reproductive age (15- $44 \mathrm{y})$ are in low- and middle-income countries. In most low-income countries, the rates of maternal malnutrition range from $10 \%$ to $19 \%$ and $>20 \%$ of women in those regions have $\mathrm{BMl}<18.5 \mathrm{~kg} / \mathrm{m}^{2}$ (Black et al., 2008).
\end{abstract}




\title{
Naeem M. Rabeh et al.,
}

Chronic energy deficiency due to an inadequate food intake may be the cause of malnutrition in adults (Finucane et al., 2011). Formulas containing herbal remedies are commonly used to prevent disease and promote health (Nahin et al., 2009). Many of these formulas are marketed irrespective of strict rules, sales conditions, and advertisement control for them (Ashcroft and Po, 1999). Nuts are an integral part of the Mediterranean food pattern which includes a substantial intake of fat up to $35 \%$ to $40 \%$ of total energy intake (Willett et al., 1995). An association was noticed between nut consumption and an increase in serum lipid and lipoprotein profiles. An increase in consumption of this energy-dense, high-fat food leads to excessive weight gain (Bes-Rastrollo et al., 2007).

Moghat plant powder is used in Egypt as tonic, nutritive ingredient to increase body weight. The effect of both plant powder and its alcoholic extract proved to be non-toxic up to $2500 \mathrm{mg} / \mathrm{kg}$ body weight in the experimental mice (El-Sayed et al., 2004). Fenugreek seed has been long used as herbal medicine to treat various pathological conditions. These seeds have glucose and lipid-lowering properties. Also antioxidant properties have been observed in animal studies (Sauvaire et al., 2000 and Choudhary et al., 2001). In addition, Rguibi and Belahsen, (2006) reported that fenugreek-based preparations are used in humans to stimulate appetite and promote weight gain. Moghat root is used in Folk medicine as tonic to increase the body weight and for the treatment of bruises, gout and spasms (Ibrahaim et al., 1997).

Molasses is a by-product of the sugar industry. It is a heavy viscous liquid, which is composed of carbohydrates (sucrose, glucose, and fructose), protein, minerals and vitamins (Elshreef, 2010). Molasses is considered to be generally regarded as safe by the U.S. Food and Drug Administration, and people believe molasses has health benefits beyond its special taste and flavor due to it,s being rich in minerals. In addition, several studies evidenced that molasses is a rich source of phenolic compounds (Guimarães et al., 2007) having possible roles in the prevention of several chronic diseases involving oxidative stress (Yao et al., 2004 and Scalbert, et al., 2005).

Natural honey is a sweet, flavorful liquid food. The use of natural honey as a nutraceutical agent is associated with nutritional benefits and therapeutic promises. Natural honey is widely accepted as food and medicine by all generations, traditions and civilizations, both ancient and modern (Ajibola et al.,2012). Various dietary carbohydrates have been linked to obesity and altered adipose metabolism; however, we hypothesized that in comparison with sucrose, a honey-based diet would promote lower weight gain, adiposity, and related biomarkers (leptin) as well as a better blood lipid profile (Nemoseck et al., 2011).

The aim of the present work is to evaluate the effect of diet supplemented with different local weight gain formulae on body weight status, liver function and hematological profile of rats.

\section{Materials and Methods}

\author{
Materials: \\ Chemicals: Casein, vitamins, minerals and cellulose were purchased from El-Gomhoria Company, Cairo, \\ Egypt. The reagents kits for blood analysis were purchased from Gama Trade Company for Chemicals, \\ Cairo, Egypt.
}

Ingredients: Different formulas ingredients, molasses, seeds, and herbals were obtained from local market called "Haraz Market". Honey, royal jelly and bee pollen were obtained from Faculty of Agriculture, Ain Shams University 


\section{Egypt. J. of Nutrition and Health Vol. 14 No. 1 January (2019)}

Methods:

The three prepared formulae were selected based on the information of their popularity in local markets for gaining weight: Formula (1) called "Mefataka" contained: (molasses, fenugreek seeds, sesame seeds, groundnuts, peanuts, almonds, wheat flour, and black seed). Formula (2) called "Kharaz El-Bakar" contained: (honey, fenugreek seeds, black seed, basil, caraway, rosemary, prunus mahaleb, almond, pistachio). Formula (3) called "Tahwijat El-kortas El-Abiad" contained: (wild yam, sesame, thymus, cinnamon, fennel, cardamom, cicer, asafetida, mahaleb, almond, fenugreek seeds, soybean).

The ingredients of each formula were mixed separately then dried in oven air drier according to the method described in (AOAC, 2005). The dried formulae were milled into powder then packed in polyethylene bags and kept at $4^{\circ} \mathrm{C}$ until used.

\section{Biological study:}

This study was carried out at the Animal House of Agriculture Research Center. The studied formulae were mixed with other ingredients of the basal diet, at the level of $(10 \%$ and $15 \%)$ from each formula in case of the selection of the dose for long-term treatment (Mossberg and Hayes, 1989).

A total number of forty two adult male albino rats (Sprague-Dawley strain) weighing approximately (110 $\pm 5 \mathrm{~g}$ ) were purchased from Experimental Animals Station, Agricultural Research Center, Giza, Egypt and were housed in well aerated cages under hygienic conditions. They were fed on basal diet for one week for adaptation. All diets were formulated to cover the nutrient requirements of rats following the recommendations of the American Institute of Nutrition (AIN-93M) (Reeves et al., 1993).

After this week rats were divided into seven groups (6 rats each) as follows:-

Group (1) was fed on basal diet and kept as a control group. Groups (2 and 3) were fed on basal diet supplemented with "Mefataka" formula at the level of $10 \%$ and $15 \%$ respectively replacement from starch in basal diet. Groups (4 and 5) were fed on basal diet supplemented with "Kharaz El-Bakar" formula at the level of $10 \%$ and $15 \%$ respectively replacement from starch in basal diet. Groups (6 and 7 ) were fed on basal diet supplemented with "Tahwijat El-kortas El-Abiad" formula at the level of $10 \%$ and $15 \%$ respectively replacement from starch in basal diet.

At the end of the experimental period (8 weeks), rats were fasted overnight before sacrificing. Two blood samples were collected from medial canthus of the eyes of each rat by means of fine capillary glass tubes. The first sample was collected into a tube containing disodium salt of Ethylene Diamine Tetra Acetic Acid (EDTA) as anticoagulant and used for assessment of hematological parameters. These parameters were quantified by standard hematological assay analyzer. The second blood sample was collected into a centrifuge tube without any anticoagulant and centrifuged for 15 minutes at 3000 r.p.m. to obtain serum which was stored at $-20^{\circ} \mathrm{C}$ until used for subsequent biochemical analysis.

\section{Chemical composition:}

Moisture, protein, crude fiber, fat, and ash contents were determined in the prepared formulas according to the method of AOAC (2005). Total carbohydrate was calculated by difference. Caloric value of the formulas was calculated by using the factors as described by FAO/WHO, (1985) according to the following equation:

Total caloric value $=4 \times($ Protein $\%+$ Carb. $\%)+9 \times($ Fat $\%)$.

\section{Biological Evaluations:}

During the experimental period, the quantities of diet, which were consumed and/or wasted, were recorded every day while total feed intake $(\mathrm{FI})$ was calculated. In addition, rat's body weight was recorded. 


\section{Naeem M. Rabeh et al.,}

Feed efficiency ratio (FER) and body weight gain percent (BWG \%) was calculated according to Champman, et al., (1959) using the following equation:

BWG\% $=($ Final body weight - Initial body weight $) /$ Initial body weight $\times 100$

FER $=$ Weight Gain (g)/ Feed intake $(\mathrm{g})$

Biochemical analysis: The following parameters were determined in serum at the Agriculture Research Center. Serum aspartate aminotransferase (AST) and alanine aminotransferase (ALT) and alkaline phosphatase (ALP) were determined according to the method of (Bergmeyer et al., 1978).

Serum creatinine, urea and uric acid level were determined by the method Tietz, (1999); Wills and Savory, (1981) and Patton and Crouch, (1977) respectively. Leptin hormone was determined using enzyme-linked immunosorbent (ELISA) assay according to (Xiong et al., 2005). The hematological profile included red blood cell count (RBC), white blood cell count (WBC), hemoglobin (Hb), hematocrits (HCT), and white blood cell (WBC) were determined using standard hematological technique as described by

Ochei and Kolharktar, (2008).

Statistical Analysis: The obtained results were analyzed according to SPSS program version (20). ANOVA test was used to compare results among groups and $\mathrm{P}<0.05$ was considered to be the level of significance (Snedecor and Cochran, 1980).

\section{Results and discussion}

Being thin may be due to both genetic and external factors, related to the child's environment. Inadequate intakes of energy and nutrients that may be associated with the limited resources of food, stress or an unbalanced diet used in a medical disorder (e.g. allergy) or poor eating habits are the most common causes of low weight to height ratio in adolescents. Insufficient supply of protein, energy or micronutrients may lead to malnutrition, which may also result in reducing the body's resistance to pathogens, delayed physical and intellectual development or cause metabolic disorders. Underweight, although to a lesser extent than obesity, affects the morbidity of children and adolescents (Lusky et al., 1996). Underweight and obesity are associated with an increased risk of mortality compared with people of a healthy weight (AlFaris, 2014).

Table (1)

Chemical composition of local tested formulae.

\begin{tabular}{l|c|c|c}
\hline \multirow{2}{*}{ Contents } & Mefataka & Kharaz El-Bakar & El-Kortas El-Abiad \\
\cline { 2 - 4 } & \multicolumn{3}{|c}{ (\% on dry weight basis) } \\
\hline Moisture & 19.0 & 13.0 & 6.8 \\
\hline Protein & 3.4 & 3.6 & 15.8 \\
\hline Fats & 5.65 & 3.16 & 17.22 \\
\hline Fibers & 2.31 & 3.53 & 4.1 \\
\hline Ash & 1.5 & 0.81 & 44.38 \\
\hline Carbohydrates & 68.14 & 75.9 & 395.7 \\
\hline Energy (k.cal) & 337.01 & 346.44 & \\
\hline
\end{tabular}

Regarding to "Mefataka" formula, it contained protein, fat and carbohydrate $(3.4,5.65$ and $68.14 \%)$ respectively and provides a $337.01 \mathrm{~K} . \mathrm{cal} / 100 \mathrm{~g}$ dried sample. This may be attributed to the presence of molasses, fenugreek seeds, sesame seeds, groundnuts, peanuts, almonds, wheat flour, and black seed and 


\section{Egypt. J. of Nutrition and Health Vol. 14 No. 1 January (2019)}

nuts. Kharaz El-Bakar formula contains honey, fenugreek seeds, black seed, basil, caraway, rosemary, prunus mahaleb, almond and pistachio, while it contains a low percent of Fats $(3.16 \%)$ and high percent of carbohydrate $(75.9 \%)$ and provides a $346.44 \mathrm{~K} . c a l / 100 \mathrm{~g}$ dried sample. While the formula "Tahwijat ElKortas El-Abiad" contained high percent of protein, fat, Fibers and Ash (15.8, 17.22, 11.7 and 4.1\%) respectively and provided a $395.7 \mathrm{~K} . \mathrm{cal} / 100 \mathrm{~g}$ dried sample compared to the other studied formulas. The high caloric content may be due to wild yam, sesame, thymus, cinnamon, fennel, cardamom, cicer, asafetida, mahaleb, almond, fenugreek seeds, soybean or / and nuts content of the formula

In this respect, Sabate and Wien, (2010) reported that, nuts are an energy dense food as they contain between $44 \%$ to $76 \%$ total fat by weight. Mattes and Dreher, (2010) indicated that nuts are rich source of fat (up to $70 \%$ ) and protein $(10-25 \mathrm{~g} / 100 \mathrm{~g})$. Moreover, feeding Sesame seeds at $10 \%$ increased BWG\% (15.97\%) and improved FER (0.95 \pm 0.01$)$ in diabetic rats compared to the control positive group (Ibrahiem et al., 2016).

The obtained results in Table (2) revealed that final body weight FBW and body weight gain BWG\% were significantly increased in rats fed on different formula at the two levels, compared to the control group. There were no difference in FBW and BWG\% between the groups fed on Kharaz El-Bakar 10\% and Kharaz El-Bakar 15\%. The higher levels of Mefataka or El-Kortas El-Abiad the higher weight gain were observed. In respect to FER, all studied formula at the two levels significantly increased the FER, compared to the control group.

Table (2)

Effect of diet supplemented with different formulas on body weight status in rats.

\begin{tabular}{|c|c|c|c|c|c|}
\hline Groups $\quad$ Parameters & IBW (g) & FBW $(g)$ & BWG\% & $\begin{array}{c}\mathrm{FI} \\
\text { (g/day/rat) }\end{array}$ & FER \\
\hline Control & $104.32 \pm 1.89^{\mathrm{a}}$ & $117.62 \pm 1.81^{d}$ & $12.77 \pm 0.99^{d}$ & 11.30 & $0.019 \pm 0.001^{\mathrm{e}}$ \\
\hline Mefataka $10 \%$ & $105.82 \pm 1.66^{a}$ & $137.22 \pm 2.88^{C}$ & $29.81 \pm 3.97^{c}$ & 12.50 & $0.041 \pm 0.005^{c}$ \\
\hline Mefataka $15 \%$ & $108.75 \pm 0.47^{a}$ & $158.17 \pm 2.61^{b}$ & $45.45 \pm 2.50^{b}$ & 14.10 & $0.058 \pm 0.003^{b}$ \\
\hline Kharaz El-Bakar 10\% & $105.75 \pm 0.25^{a}$ & $132.45 \pm 2.09^{c}$ & $25.24 \pm 1.81^{\mathrm{c}}$ & 11.80 & $0.037 \pm 0.002^{c d}$ \\
\hline Kharaz El-Bakar 15\% & $108.25 \pm 1.10^{a}$ & $132.75 \pm 1.10^{c}$ & $22.64 \pm 0.56^{c}$ & 13.00 & $0.031 \pm 0.000^{d}$ \\
\hline El-Kortas El-Abiad 10\% & $104.95 \pm 1.34^{a}$ & $161.37 \pm 3.62^{b}$ & $53.74 \pm 2.47^{b}$ & 14.20 & $0.066 \pm 0.003^{b}$ \\
\hline El-Kortas El-Abiad 15\% & $106.10 \pm 2.15^{a}$ & $198.77 \pm 2.38^{a}$ & $87.66 \pm 5.59^{a}$ & 15.60 & $0.099 \pm 0.004^{a}$ \\
\hline
\end{tabular}

Mean values are expressed as means \pm SE.

Means with different superscript letters in the column are significantly different at $P<0.05$.

IBW: initial body weight

FBW: final body weight

BWG: body weight gain

FI: food intake

FER: food efficiency ratio

The higher levels of Mefataka or El-Kortas El-Abiad the higher FER were recorded. The highest BWG\% and FER were recorded at the group fed on diet supplemented with 15\% Tahwijat El-kortas ElAbiad. This may be ascribed to the quality of the tested formulas; in addition to, the local formulas have high calorific value as mentioned in Table (1). 


\section{Naeem M. Rabeh et al.,}

The primary factors contributing to the predicted effects of nut consumption on BWG are their strong satiety effects (Mattes et al., 2008). The current results are in agreement to the results obtained by Bes-Rastrollo et al., (2007) who indicated that nut consumption was positively associated with higher values of total fat and total energy intake which lead to gain weight. Also Rguibi and Belahsen, (2006) reported that fenugreek-based preparations are used in humans to stimulate appetite and promote weight gain. Nuts contain fiber, protein, unsaturated fats and various phytochemicals and have distinct flavor profiles. So that nuts are widely believed to be energy- rich food (Kirkmeyer and Mattes, 2000).

Sugar cane molasses is a viscous and dark coloured liquid which is rich in soluble carbohydrate, vitamins, minerals and other materials. Some of the mineral contents are; iron, zinc, copper, manganese, potassium, sodium, calcium and vitamin B complex (Curtin, 1983). Sugarcane molasses has several important roles in livestock feeding due to the nutritive, appetizing and physical properties of its sugar content.

Table (3)

Effect of diet supplemented with the tested formulae on leptin hormone in rats.

\begin{tabular}{|c|c|}
\hline Groups $\quad$ Parameters & Leptin hormone $(\mu \mathrm{g} / \mathrm{l})$ \\
\hline Control & $1.91 \pm 0.02^{e}$ \\
\hline Mefataka $10 \%$ & $2.69 \pm 0.04^{c}$ \\
\hline Mefataka $15 \%$ & $2.94 \pm 0.03^{\mathrm{ab}}$ \\
\hline Kharaz El-Bakar 10\% & $2.32 \pm 0.04^{\mathrm{d}}$ \\
\hline Kharaz El-Bakar 15\% & $2.58 \pm 0.03^{\mathrm{C}}$ \\
\hline El-Kortas El-Abiad 10\% & $2.88 \pm 0.04^{b}$ \\
\hline El-Kortas El-Abiad 15\% & $3.02 \pm 0.02^{\mathrm{a}}$ \\
\hline
\end{tabular}

Mean values are expressed as means \pm SE.

Means with different superscript letters in the column are significantly different at $P<0.05$.

Results illustrated in table (3) show the effect of diet supplemented with the local formulae (Mefataka, Kharaz El-Bakar and El-Kortas El-Abiad) at different levels on serum leptin hormone in rats. There was a significant increase in serum leptin hormone for all studied formulae at 10 and $15 \%$, compared to the control group. The higher level of Mefataka, Kharaz El-Bakar or El-Kortas El-Abiad the higher leptin hormone was recorded. The highest leptin hormone was observed at the group fed on diet supplemented with Mefataka $15 \%$ or El-Kortas El-Abiad 15\% (2.94 \pm 0.03 and $3.02 \pm 0.02 \mu \mathrm{g} / \mathrm{l})$.

Leptin is a hormone that is produced by the body's fat cells (Margetic et al., 2002). It is often referred to as the "satiety hormone" or the "starvation hormone". Leptin's primary target is in the brain, at the hypothalamus. Leptin is supposed to tell the brain that we have enough fat stored, that we don't need to eat and that we can burn calories at a normal rate (Chan et al ., 2003).

The possibility that falling plasma leptin levels signal nutrient deprivation is further suggested by the observation that exogenous leptin attenuates the neuroendocrine responses to food restriction (Ahima et al., 1996). The plasma level of leptin is highly correlated with adipose tissue mass and decreases in both humans and mice after weight loss (Maffei et al., 1995). Other studies reported significant positive correlation between plasma leptin levels and epididymal fat mass, liver and heart weights ( HandjievaDarlenska and Boyadjieva, 2009). 


\section{Egypt. J. of Nutrition and Health Vol. 14 No. 1 January (2019)}

The effect of diet supplemented with local weight gain formula on liver functions in rats was recorded in Table (4)

Table (4)

Effect of diet supplemented with the tested formulae on liver functions in rats.

\begin{tabular}{|c|c|c|c|}
\hline \multirow{2}{*}{ Groups $\quad$ Parameters } & AST & ALT & ALP \\
\hline & \multicolumn{3}{|c|}{$(\mu / l)$} \\
\hline Control & $52.85 \pm 2.46^{\mathrm{a}}$ & $76.75 \pm 1.25^{\mathrm{a}}$ & $2.12 \pm 0.35^{a}$ \\
\hline Mefataka $10 \%$ & $49.65 \pm 0.54^{\mathrm{a}}$ & $76.50 \pm 1.32^{\mathrm{a}}$ & $2.77 \pm 0.10^{\mathrm{a}}$ \\
\hline Mefataka $15 \%$ & $47.12 \pm 1.05^{\mathrm{a}}$ & $71.25 \pm 1.31^{\mathrm{a}}$ & $2.60 \pm 0.23^{a}$ \\
\hline Kharaz El-Bakar 10\% & $52.00 \pm 3.37^{\mathrm{a}}$ & $75.00 \pm 2.92^{\mathrm{a}}$ & $2.39 \pm 0.29^{a}$ \\
\hline Kharaz El-Bakar 15\% & $48.70 \pm 2.29^{\mathrm{a}}$ & $72.17 \pm 1.51^{\mathrm{a}}$ & $2.29 \pm 0.19^{a}$ \\
\hline El-Kortas El-Abiad 10\% & $47.25 \pm 1.31^{\mathrm{a}}$ & $73.80 \pm 1.84^{\mathrm{a}}$ & $2.44 \pm 0.12^{a}$ \\
\hline El-Kortas El-Abiad 15\% & $50.75 \pm 2.53^{\mathrm{a}}$ & $74.50 \pm 1.26^{\mathrm{a}}$ & $2.26 \pm 0.10^{a}$ \\
\hline
\end{tabular}

Mean values are expressed as means \pm SE.

Means with different superscript letters in the column are significantly different at $P<0.05$.

The results indicated that, there were no significant changes in serum liver functions (ALT, AST and ALP) among the different tested formulas and the control group.On the other hand, the effect of diet supplemented with the tested formulae on kidney functions of rats was illustrated in table (5).

Table (5)

Effect of diet supplemented with the tested formulae on kidney functions in rats.

\begin{tabular}{l|l|l|l}
\hline \multirow{2}{*}{ Groups } & Urea & Uric acid & Creatinine \\
\cline { 2 - 4 } & \multicolumn{3}{|c}{$(\mathrm{mg} / \mathrm{dl})$} \\
\hline Control & $70.37 \pm 2.84^{\mathrm{a}}$ & $3.21 \pm 0.25^{\mathrm{a}}$ & $0.870 \pm 0.05^{\mathrm{a}}$ \\
\hline Mefataka 10\% & $63.07 \pm 2.29^{\mathrm{ab}}$ & $1.90 \pm 0.18^{\mathrm{bc}}$ & $0.625 \pm 0.05^{\mathrm{b}}$ \\
\hline Mefataka 15\% & $52.57 \pm 2.52^{\mathrm{cd}}$ & $1.87 \pm 0.24^{\mathrm{bc}}$ & $0.547 \pm 0.03^{\mathrm{b}}$ \\
\hline Kharaz El-Bakar 10\% & $59.55 \pm 2.68^{\mathrm{bc}}$ & $2.35 \pm 0.12^{\mathrm{bc}}$ & $0.627 \pm 0.05^{\mathrm{b}}$ \\
\hline Kharaz El-Bakar 15\% & $55.92 \pm 2.65^{\mathrm{bcd}}$ & $2.57 \pm 0.28^{\mathrm{ab}}$ & $0.682 \pm 0.04^{\mathrm{b}}$ \\
\hline El-Kortas El-Abiad 10\% & $63.20 \pm 3.65^{\mathrm{ab}}$ & $1.97 \pm 0.29^{\mathrm{bc}}$ & $0.660 \pm 0.06^{\mathrm{b}}$ \\
\hline El-Kortas El-Abiad 15\% & $49.00 \pm 3.50^{\mathrm{d}}$ & $1.82 \pm 0.13^{\mathrm{c}}$ & $0.562 \pm 0.02^{\mathrm{b}}$ \\
\hline
\end{tabular}

Mean values are expressed as means \pm SE.

Means with different superscript letters in the column are significantly different at $P<0.05$.

The results in table (5) indicated the effect of diet supplemented with local weight gain formulae on kidney functions hormone in rats. No significant change was observed in serum urea among the groups fed on Mefataka 10\%, El-Kortas El-Abiad 10\% and the control group. However, the rats fed on Mefataka $15 \%$ or Kharaz El-Bakar at $(10 \%$ \& $15 \%)$ or El-Kortas El-Abiad 15\% formula had significant $(\mathrm{P}<0.05)$ decrease in serum urea compared to the control group. There was a significant decrease in serum creatinine for all studied formula at 10 and $15 \%$, compared to the control group.

Moreover, there was no significant change in the level of creatinine among all tested formulae. In respect to uric acid, all studied formulae except for Kharaz El-Bakar $15 \%$ significantly $(\mathrm{P}<0.05)$ decreased serum uric acid, compared to the control group. There was no significant change in serum uric acid among the groups fed on diet supplemented with Mefataka at (10 \& 15\%), Kharaz El-Bakar at (10 \& 15\%) and ElKortas El-Abiad at 10\%. 


\section{Naeem M. Rabeh et al.,}

This could be attributed to good quality of ingredients used in tested formulas. In this respect, Sabate and Wien, (2010) indicated that nuts as hazelnuts and peanut are excellent natural sources of antioxidant, vitamins, minerals as well as nuts contained many bioactive constituents.

The tested formulae Mefataka, Kharaz El-Bakar and Tahwijat El-kortas El-Abiad have sesame seed content which has been used as a source of healthful foods and of essential Sesame oil. The seeds are rich source of many essential minerals. Sesame oil is one of the most stable vegetable oils and it contains high content of natural antioxidant lignans as sesamin, sesamolin and sesamol (Mahendra and Singh, 2015). Sesame produced protective effect against $\mathrm{CCL}_{4}$-induced hepatotoxicity in mice (Ma et al., 2014). Furthermore, Nigella sativa and Sesame seeds feeding to diabetic rats produced nephroprotective and renal tissue antioxidant effects (Dollah et al., 2013 and Erboga et al., 2015).

Table (6)

Effect of diet supplemented with the tested formulae on RBC parameters and WBC of rats.

\begin{tabular}{|c|c|c|c|c|}
\hline Groups $\quad$ Parameters & $\operatorname{RBC}(106 / \mathrm{ml})$ & $\mathrm{Hb}(\mathrm{g} / \mathrm{dl})$ & Hct (\%) & WBC \\
\hline Control & $5.84 \pm 5.84 \mathrm{c}$ & $11.47 \pm 0.31 \mathrm{c}$ & $35.55 \pm 0.52 c$ & $9.86 \pm 0.63 a$ \\
\hline Mefataka $10 \%$ & $8.24 \pm 8.24 b$ & $12.70 \pm 0.74 b c$ & $39.57 \pm 0.77 b$ & $8.26 \pm 0.49 a$ \\
\hline Mefataka 15\% & $10.14 \pm 1.15 a$ & $13.75 \pm 0.36 b$ & $40.10 \pm 0.29 b$ & $8.31 \pm 0.31 a$ \\
\hline Kharaz El-Bakar 10\% & $7.54 \pm 7.55 b$ & $13.10 \pm 0.53 b$ & $38.90 \pm 0.69 b$ & $8.15 \pm 0.49 a$ \\
\hline Kharaz El-Bakar 15\% & $7.57 \pm 7.57 b$ & $13.52 \pm 0.37 b$ & $40.62 \pm 1.24 b$ & $8.72 \pm 0.75 a$ \\
\hline El-Kortas El-Abiad 10\% & $8.94 \pm 8.94 a b$ & $15.45 \pm 0.33 a$ & $42.85 \pm 0.43 a$ & $8.92 \pm 0.82 a$ \\
\hline El-Kortas El-Abiad 15\% & $10.00 \pm 10.01 a$ & $15.87 \pm 0.41 \mathrm{a}$ & $44.36 \pm 0.65 a$ & $8.69 \pm 0.77 a$ \\
\hline
\end{tabular}

Values were expressed as Means \pm SE.

Values at the same column with different letters are significant at $\mathrm{P}<0.05$.

The obtained results in table (6) indicate that, the consumption of the tested formulae caused a significant increase $(\mathrm{P}<0.05)$ in the mean values of $\mathrm{RBC}, \mathrm{Hb}$ and $\mathrm{Hct}$, compared to the corresponding value of the control group. However, no significant change was observed for WBC among all tested formulae compared to the control group. Moreover, the supplementation with Mefataka $15 \%$ formula caused a higher significant $(\mathrm{P}<0.05)$ increase in RBC than Mefataka 10\%. It could be also observed that, rats fed on diet supplemented with El-Kortas El-Abiad 15\% formula had a higher increase in $\mathrm{Hb}$ and Hct than other rats because it continued good sources of iron.

Haematology tests are important in evaluating the health and nutritional status of animals (Gupta et al., 2007). The effect of molasses supplementation $(5-7 \mathrm{ml})$ to drinking water on liver weight gain, haematologic parameters and erythrocyte osmotic fragility in 7-week-old broiler chickens was studied by Habibu et al., (2014). The percentage weight gain, mean corpuscular haemoglobin concentration $(P<0.05)$ and mean corpuscular volume were significantly higher $(P<0.01)$ in chickens given 5 and $7 \mathrm{ml}$ than control.

Moreover, Elseed et al., (2013) found that fenugreek saponins extract (1 g of saponins extract/day) to the diet concluded positive effects on production, hematological parameters and blood metabolites of rabbits. 


\section{Egypt. J. of Nutrition and Health Vol. 14 No. 1 January (2019)}

Recommendation: we conclude that the tested formulae increased body weight of rats with no harm on the hematological parameters, liver and kidney function. These findings indicate that Mefataka, Kharaz El-Bakar and Tahwijat El-kortas El-Abiad formulae at 10 and $15 \%$ of the tested diet may be used by slim individuals to stimulate appetite and enhance weight gain effectively.

\section{References}

Ahima R.S.; Prabakaran D.; Mantzoros C. and et al., (1996):

Role of leptin in the neuroendocrine response to fasting. Nature; 382:250 -252

Ajibola A.; Chamunorwa. J.P. and Erlwanger K.H. (2012):

Nutraceutical values of natural honey and its contribution to human health and wealth. Nutr Metab (Lond).; 9: 61.

Al-Faris N. (2014):

Nutritional and Safety Evaluation of Local Weight-Gain Formulas in the Kingdom of Saudi Arabia (KSA) Markets.. Food and Nutrition Sciences. 5: 1341-1351.

Ashcroft D.M. and Po A.L. (1999):

Herbal Remedies: Issues in Licensing and Economic Evaluation. Pharmacoeconomics. 16: $321-$ 328.

AOAC (Association of Official Analytical Chemist), (2005):

Official Method of Analytical Chemist. $18^{\text {th }}$ Edition. AOAC. Washington DC.

Bes-Rastrollo M.; Sabaté J.; Gómez-Gracia E.; Alonso A.; Martinez J.A. and Martínez- González M.A. (2007):

Nut Consumption and Weight Gain in a Mediterranean Chort: The Sun Study. Obesity, 15:107-116.

Black R.E.; Allen L.H.; Bhutta Z.A.; Caulfield L.E.; De Onis M.; Ezzati M.; Mathers C. and Rivera J. (2008):

Maternal and Child Undernutrition Study Group. Maternal and Child Undernutrition: Global and Regional Expoures and Health Consequences. Lancet. 371:243-260.

Bergmeyer H.; Schreiber P. and Wahlefeld A. (1978):

"Optimization of methods for aspartate and alanine aminotransferase". Clin Chem. 24:58-61.

Chan J.; Heist K.; DePaoli A.; Veldhuis J. and Mantzoros C. (2003):

The role of falling leptin levels in the neuroendocrine and metabolic adaptation to short-term starvation in healthy men., J Clin Invest.,111(9):1409-1421

Champman D.G.; Castilla R. and Compel J.A. (1959):

"Evaluation of protein in foods. I-A: method for determination of protein efficiency ratio". Can. J. Biochem Physiol., 37: 679 - 686. 


\section{Naeem M. Rabeh et al.,}

Choudhary D.; Chandra D.; Choudhary S. and Kale R.K. (2001):

Modulation of Glyoxalase. Glutathione S-Transferase and Antioxidant Enzymes in the Liver. Spleen and Erythrocytes of Mice by Dietary Administration of Fenugreek Seeds. Food and Chemical Toxicology. 39:989-997.

Curtin L.V. (1983):

Molasses - general considerations.National Feed Ingredients Association, West DesMoines, lowa, USA.

Dollah M.A.; Parhizkar S. and Izwan M. (2013):

Effect of Nigella sativa on the kidney function in rats. Avicenna J. Phytomed., 3(2):152-158.

El-Sayed N.H.; Awaad A.S. and Mabry J.J. (2004):

Phytochemical Studies and Effect on Urine Volume of Gossostemon bruguieri Desf. Constituents. Indian Journal of Experimental Biology. 42:186-189.

Elseed A.; Danil A.M.; Abu ElgaimAtta T.; Elmanan B. and Ali O. (2013):

Effects of Fenugreek (Trigonella foenumgraecum) Seeds Saponin on Digestibility, N- Retention, Hematological parameters and blood Metabolites in Rabbits. World's Vet. J. 3(3): 65-73.

Elshreef A.Y.(2010):

Effect of Molasses Levels Source of Energy on Broiler Performance. Faculty Of Veterinary Medicine and Animal production. Sudan University of scence and technology.

Erboga M.; Kanter M.; Aktas C.; Sener U.; Erboga Z.; Bozdemir D.Y. and Gurel A. (2015):

Thymoquinone Ameliorates Cadmium-Induced Nephrotoxicity. Apoptosis. and Oxidative Stress in Rats is Based on its Anti-Apoptotic and Anti-Oxidant Properties. Biol. Trace Elem. Res., 1:1-8.

Ezzati M.; Lopez A.D.; Rodgers A.; Vander Hoorn S. and Murray C.J. (2002):

Comparative Risk Assessment Collaborating Group Selected Major Risk Factors and Global and Regional Burden of Disease. Lancet. 360:1347-1360.

Finucane M.M.; Stevens G.A.; Cowan M.J. and et al., (2011):

Global Burden of Metabolic Risk Factors of Chronic Diseases Collaborating Group (Body Mass Index) National. Regional. and Global Trends in Body-Mass Index Since 1980: Systematic Analysis of Health Examination Surveys and Epidemiological Studies with 960 Country-Years and 9.1 Million Participants. Lancet. 377:557-567.

Food and Agriculture Organization/ World Health Organization (FAO/WHO) (1985):

Energy and Protein Requirements. Report of a Joint FAO/WHO/UNU Expert Consultation Technical Report. Series No. 724. FAO/WHO. Geneva.

Gamel T.H.; Abd EL-Razek A.M. and Damir A.A. (2010):

Dried peeled roots of glossostemon bruguieri(moghat) as a potential functional food.. $\mathrm{J}$ of Food Processing and Preservation.. 34. (1) :55-67 


\section{Egypt. J. of Nutrition and Health Vol. 14 No. 1 January (2019)}

Ghareeb D.A.; El-Rashidy F.H. and El-Mallawany S. (2014):

Imbalanced Diet Deficient in Calcium and Vitamin D Induced Juvenile Ostopenia in Rats; The Potential Effect of Egyptian Moghat Roots Water Extract 123 (Gossostemon bruguieri). Iranian Journal of Pharmaceutical Research., 13: 623-634.

Guimarães C.M.; Gião M.S.; Martinez S.S.; Pintado A.I.; Pintado M.E.; Bento L.S.; Malcata F.X. (2007): Antioxidant activity of sugar molasses. including protective effect against DNA oxidative damage. J. Food Sci., 72. C039-C043.

Gunaid A.A. and Assabri A.M. (2008):

Prevalence of Type 2 Diabetes and Other Cardiovascular Risk Factors in a Semirural Area in Yemen. La Revue de Santé de la Méditerranée Orientale. 14: 42-56.

Gupta, A.R.; Putra, R.C.; Sani, M. and Swarup, D. (2007):

Haematology and serum biochemistry of Chital (Axis axis) and barking deer (Muntiacus muntijax) reared in semi-captivity. Veterinary Research Communications, 31: $801-808$.

Habibu B.; Ikira N.M.; Buhari HU.; Aluwong T.; Kawu MU.; Yaqub LS.; Tauheed M. and Isa HI. (2014): Effect of Molasses Supplementation on Live Weight Gain, Haematologic Parameters and Erythrocyte Osmotic Fragility of Broiler Chickens in the Hot-dry Season, International Journal of Veterinary Science., 3(4): 181-188.

Handjieva-Darlenska, T. and Boyadjieva, N. (2009):

"The effect of high-fat diet on plasma ghrelin and leptin levels in rats", J Physiol Biochem.;65(2): 157-164.

Ibrahaim N.; El-Eraky W.; El-Gengaihi S. and Shalaby. A. (1997):

Chemical and biological evaluation of proteins and mucilage from roots and seeds of Glossostemon bruguieri Desf (Moghat). . Plant Foods Hum. Nut. ; 50:55-61.

Ibrahiem T.A. (2016):

Beneficial Effects of Diet Supplementation with Nigella sativa (Black Seed) and Sesame Seeds in Alloxan-Diabetic Rats. Int. J. Curr. Microbiol. App. Sci., 5(1): 411-423

Kirkmeyer S.V. and Mattes R.D . (2000):

Effects of food attributes on hunger and food intake. Int J Obes Relat Metab Disord.;24:1167-75.

Lusky A; Barell V; Lubin F.; Kaplan G.; Layani V.; Shohat Z.; Lev B. and Wiener M. (1996):

Relationship between morbidity and extreme values of body mass index in adolescents. Int $\mathrm{J}$ Epidemiol 25(4): 829-834.

Ma J.Q.; Ding J.; Zhang L. and Liu C.M. (2014):

Hepatoprotective properties of sesamin against $\mathrm{CCl} 4$ induced oxidative stress-mediated apoptosis in mice via JNK pathway. Food Chem.Toxicol.; 64:41-48.

Maffei M.; Halaas J.; Ravussin E. and et al., (1995): Leptin levels in human and rodent: measurement of plasma leptin and ob RNA in obese and weight-reduced subjects. Nat Med 1995;1(11):1155-1161 


\section{Naeem M. Rabeh et al.,}

Mahan L.K. and Escott-Stump S. (2000):

Krause's Food. Nutrition \& Diet Therapy. $10^{\text {th }}$ Edition. W.B. Saunders Co..Pennsylvania.

Mahendra K.C. and Singh S.A. (2015):

Bioactive lignans from Sesame (Sesamum indicum L.): evaluation of their antioxidant and antibacterial effects for food applications. J. Food Sci. Technol.; 52(5):2934-2941.

Mattes R. and Dreher M. (2010):

Nuts and Healthy Body Weight Maintenance Mechanisms. Asia Pacific Journal of Clinical Nutrition. 19: 137-141.

Mattes R.D.; Kris-Etherton P.M. and Foster G.D. (2008):

Impact of peanuts and tree nuts on body weight and health weight loss in adults. J Nut;; 138:1741S-5

Margetic S.; Gazzola C.; Pegg G.G. and Hill R.A. (2002):

Leptin: a review of its peripheral actions and interactions. Int $\mathrm{J}$ Obes Relat Metab Disord. Nov; 26(11):1407-33.

Mossberg A.T. and Hayes A.W. (1989):

Sub-Chronic Toxicity testing. In: Hayes. A.W.. Ed.. Principles and Methods of Toxicology. 2n d Edition. Raven Press. New York. 221-236.

Nahin R.L.; Barnes P.M.; Stussman B.J. and Bloom B. (2009):

Costs of Complementary and Alternative Medicine (CAM) and Frequency of Visits to CAM Practitioners: United States. 2007. National Health Statistics Reports. 18:1- 14.

National Nutrient Database. Agricultural Research Service (USDA) (2016):

"Full Report (All Nutrients): 19296. Honey". USDA National Nutrient Database. Agricultural Research Service. Revised May. 2016. Release 8 July 2017.

Ndelekwute E.K.; Uzegbu H.O.; Igwe I.R.; Nosike R.J.; Odoemelam V.U. and Inyan U.O. (2010) :

Effects of administration of molasses through drinking water on growth and conformation parameters of meat-type chicken. Anim Prod Res Advan, 6: 30-34.

Nemoseck T.M.; Carmody E.G.; Furchner-Evanson A.. Gleason M.; Li A.; Potter H.;Rezende L.M.; Lane K.J. and Kern M.(2011):

Honey promotes lower weight gain. adiposity. and triglycerides than sucrose in rats. Nutr Res.;31(1):55-60.

Ochei J. and Kolhatkar A. ( 2008 ):

Medical Laboratory Sciences; Theory and Practice. Tata McGraw-Hill Publishing Co. Ltd. New Delhi; 321-32.

Patton C.J. and Crouch S.R. (1977):

Calorimetric determination of blood urea. Analyt.Chem.. 49: 464-469. 


\section{Egypt. J. of Nutrition and Health Vol. 14 No. 1 January (2019)}

Pérez R. (1995):

Molasses. In: Tropical Feeds and Feeding Systems, First FAO Electronic Conference.

Reeves R.G.; Nielsen. F.H. and Fahey. G.C. (1993):

AIN-93 Purified Diets for Laboratory Rodents .J. Nutr.. 123(1):1939-1951.

Rguibi M. and Belahsen R. (2006):

Body Size Preferences and Socio Cultural Influences on Attitudes towards Obesity among Moroccan Sahraoui Women. Body Image. 3:395-400.

Sabate J. and Wein M. (2010):

Nuts. Blood Lipids and Cardiovascular isease. Asia Pacific Journal of Clinical Nutrition. 19:131136.

Sauvaire Y.; Petit P.; Baissac Y. and Ribes G. (2000):

Chemistry and Pharmacology of Fenugreek. In: Mazza. G. and Oomah. B.D.. Eds.. Herbs. Botanicals and Teas. Technomic. Lancaster. 107-129.

Scalbert A.; Manach C.; Morand C.; Rémésy C. and Jiménez L. (2005):

Dietary polyphenols and the prevention of diseases. Crit. Rev. Food Sci. Nutr.. 45:287-306.

Snedecor G.W. and Cochran W. (1980):

Statistical methods., $7^{\text {th }}$ Ed.. lowa State University Press. Ames. USA. Page 90.

Tietz N.W. (1999):

Text book of clinical chemistry. (3 rd ed). C.A.Burtis. E.R. Ashwood. W.B. Saunders.. P .477-530 to $1241-1245$

Willett W.C.; Sacks F. and Trichopoulou A. (1995):

Mediterranean Diet Pyramid: A Cultural Model for Healthy Eating. American Journal of Clinical Nutrition. 61:14025-14065.

Wills M.R. and Savory J. (1981):

Biochemistry of renal failure. Ann. Clin. Lab. Sci.,11:292-299.

World Health Organization, (1998):

Physical Status: The Use and Interpretation of Anthropometry. Report of a WHO Expert Committee. Technical Report Series No. 854. World Health Organization. Geneva.

Xiong Y.; Shen L.; Liu K.J.; Tso P.; Xiong Y.; Wang G.; Woods S.C. and Liu K. (2005):

"Anti-obesity and antihyperglycemic effects of ginsenoside Rb1in rats". Diabetes.. 59: 2505-2512.

Yao L. H.; Jiang Y. M.; Shi J.; Tomás-Barberán F. A.; Datta N.; Singanusong R. and Chen. S. S. (2004):

Flavonoids in food and their health benefits. Plant Foods Hum. Nutr. 59: 113-122. 


\title{
Naeem M. Rabeh et al.,
}

تقييم مدي كفاعة الغذاء المدعم ببعض الخلطات المحلية علي وزن الجسم والمقاييس الهيماتولوجية في الجرذان

نعيم رابح'، هاني المصري، ايمان غلاب1، حنان الغتدور، عبير حسانين1 قسم التظذية وعلوم الأطعمة ـ كلية الإقتصاد المنزلى - جامعة حلوان

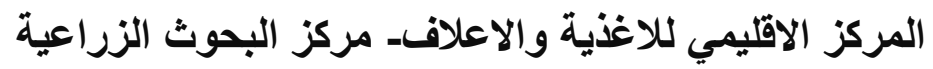

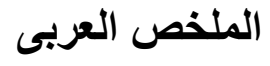

لقد ازداد في الاونة الاخيرة استخدام بعض الخلطات المحلية لزيادة الوزن معتمدة علي شعبيتها في الاسواق

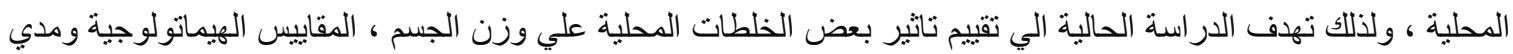

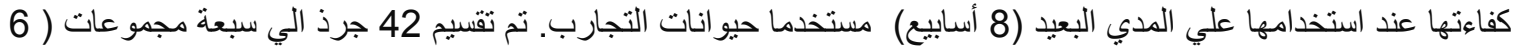

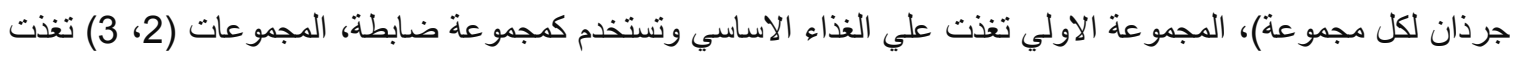

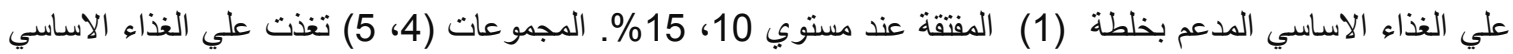

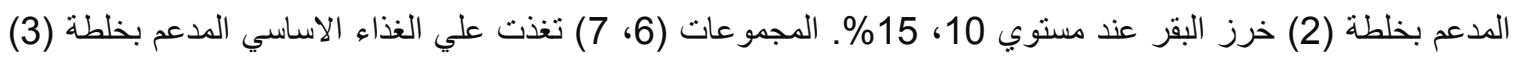

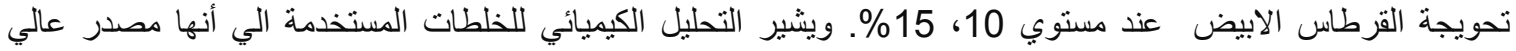

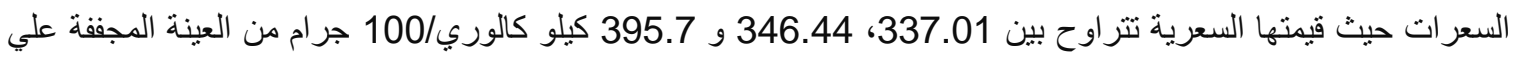

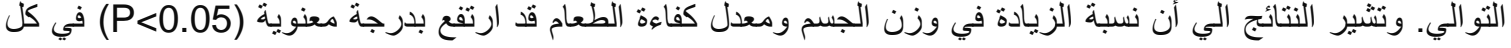

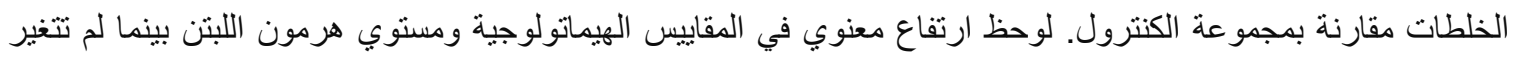
وظائف الكبد و الكلي للمجمو عات التي تغذت علي الخلطات المختلفة مقارنة بالكنترول.

التوصيات: نترح تجربة هذه الخلطات (المفتقة، خرز البقر، تحويجة القرطاس الابيض) علي الاشخاص النحفاء

وذلك لتحفيز الشهية وزيادة اوز انهم. 